\title{
CHANGES IN THE TECHNICAL FORMAT OF KATHAK IN THE VARIOUS HISTORICAL EPOCHS
}

\author{
Dr. Mansi Saxena
}

Department of Dance, P.G. Govt. College for Girls, Chandigarh

\section{ABSTRACT}

There have been changes in the technical aspects of Kathak in various historical eras starting from the Vedic period up till the Modern Era. In the Vedic Era, the technique of the dance form included the story telling format knitted with facial expressions and body movements. For depicting the philosophical interpretation of the cyclic nature of life, pirouettes were also added in the technical aspects of the dance form in the Vedic Era. However, in the later years, foot movements and poses of Kathak, like Chari and Sthanaka, were also added to the already existing story telling format of the dance form. Changes in the technique of Kathak were observed in the Mughal Era also due to the Global impact of the lslamic culture. The technical format of the dance form now included movements and poses like Urap, Tirap, Laag, Daat, Mandals and Bhramari, Gaits like Mrig, Maral and Sanchi and technical pieces like Tora, Paran, Ashwa Paran, Primalu and Tatkar during the Mughal Era. Under the impact of globalization, there have been changes in the technical format of Kathak in the modern era. Fusion of the technical movements of Kathak with other dance forms, like the contemporary dance, Chhau, Kalaripayatu and with gymnastics, has been done by Kathak artistes.

Also, changes in the traditional movements of Kathak by 'Gharanedar' artistes like Krishan Mohan Mishra who has innovated 'Bayei hath ka sam', innovation of 'Shringarik That' by Ram Mohan Maharaj, all these changes definitely highlights the change in the thinking process of these artistes and hence their dance form, Kathak which ultimately leads to the nourishment of the dance form in the present globalized society.

Key Words : Kathak, Dance Gharana

\section{INTRODUCTION}

Technique holds an important place in all the classical dance forms including Kathak. Infact, a technically strong and well defined Kathak performance leaves a long lasting impact on the audience. "Kathak', which we call 'Khubsurat, is marked by an overall pleasantness of the dancer's visage and bodily bearing. But the more important detail, here, is emphasis on shapely design and dovetailing of elements, or on a 'formed quality'. Without it, dance will be merely pleasant or agreeable. Indeed, when the rasika really finds a Kathak recital beautiful, he is quietly charmed by the easy but effective way in which limbs are all alike made to go with the bols that is to heighten their formal character." (Sushil Kumar Saxena, 2006)

From above, we can say that the beauty of the technical execution of the Kathak performance makes it charming and effective. Also, it may be assumed that the Techniquenof Kathak in the present times is defined under bodily design and lining i.e. it includes body movements, foot work, pirouettes of the Nritta, Nritya and Natya ang of the classical dance form.

With the change in the political and social environment of the different historical eras, there have been changes in the various elements of Kathak dance form including its Techique. This can be explained by turning the pages of History.

1 Sushil kumar Saxena - Swinging Syllables Aesthetics of Kathak Dance. 
PIROUETTES AS A TECHNICAL ASPECT OF KATHAK IN THE VEDIC ERA

Technique of Kathak formed an outline in the Vedic era where community of Kathaks included the Brahmin community.

Kathaks, ${ }^{1}$ being Brahmin priests were well versed in philosophy. As a part of the philosophical interpretation in the sub-continent, it is believed that every aspect of life is cyclic in nature i.e. life-death, day-night, seasons, time etc. Thus, this cyclic nature was given visual representations through pirouettes by the Kathaks. They used space as their canvas for the painting drawn by body movements. Thus, interpretation of cyclic nature of life, one of the important features of Hinduism, was represented through pirouettes." [Shovana Narayan -2005]

Above lines depict that the Brahmin community of Kathaks followed a technical format which included basic movements of the dance form like pirouettes etc. and were prevalent from the Vedic age only.

\section{ADDITION OF FOOT MOVEMENTS IN THE TECHNICAL ASPECTS OF KATHAK}

After the Vedic Era, there was spurt in the temple building activities with walls, stupas etc. embellished with the dancing figures of various divinities. Their poses not only are found to have similarities with the classical dance form, Kathak, but they also throw light on the Technique of Kathak during the Period.

"The figures" of Yakshis and apsaras from Patiputra, Bharhut,Sanchi, Kausabi, Mathura,Jhansi, Bodh Gaya \& Deoghar indicate dance movements practiced in the region. Some of the recesses in the ruins of Nalanda show dancing "apsaras" in Poses similar to the ones used in Kathak."(Shovana Narayan-2005)

From above, it may be assumed that dance prevalent in the era was similar to that of Kathak." The "3temples of Raja Rani of Parasuramesvara and of Lingraja, all reverberate with music and dance. Looked at it closely, one is impressed by the fact that the sculptor was not only a keen observer of movement, but was also a self-conscious illustrator of the basic position i.e. sthanakas \& fundamental movements like Chari described in the Natyashastra. [Kapila Vatsyayan, 1965]

Hence, we can be say that the dance form might have been technically composed of the fundamental movements like Chari and Sthanaka, , all based on the tenants of Natyashastra, in that era .

\section{GOLDEN PERIOD FOR THE DEVELOPMENT OF THE TECHNIQUE OF KATHAK IN THE}

\section{MUGHAL ERA}

During the establishment of the Mughal rule, Kathak shifted from the temple to the courts of Nawabs, no longer remained an aspect of temple rituals which further developed it into a relatively flexible classical dance style .

The Folk elements of Rasa Leela became a part of the repertoire of Kathak "Rasa Leela ${ }^{4}$ were refined folk forms of Radha Krishna dance accompanied by devotional songs \& Keertans .The gestures, whirling movements, pauses and rhythmic syllables in the text i.e. Kavit were primary folk elements that developed into an elaborate classical dance form, Kathak." [Ragini Devi,1972]

From above, it may be assumed that primary folk elements of Rasa Leela like the whirling movements, gestures as well as Kavit got incorporated into the Technique of Kathak.

1 Shovana Narayan - Indian Classical Dance

2 Shovana Narayan - Indian Classical Dance

3 Kapila Vatsyayan - The Dance in India

4 Ragini Devi - Dance Dielects of India 
"Surdas ${ }^{1}$ has quoted chapters on Swara, Tala and Nritya while extolling the beauty of Bansi performance by Lord Krishna. Also, the Ashtchap poets have described gaits-like Mriga, Maral, Sanchi etc. movements like Urap, Tirap, Bhramari and Mandals used in Kathak dance." [Projesh Banerjee -1982]

Hence, it can be said that various poses and movements were included in the technical repertoire of Kathak like Tribhangi, Urap, Tirap, Mandals. Gaits like those of Mrig, Maral etc. also became popular in this era which are even now performed as Gat Nikas in the present Kathak scenario.

\section{DIFFERENCE IN THE TECHNIQUE OF KATHAK WITHIN THE GHARANAS}

Fall of the Mughal Empire made many artists migrate from the capital to seek employment in the provincial states under local Rajas and the Nawabs after the $18^{\text {th }}$ century. The influence of the court and the temple gave rise to different aspects of the dance form. Consequently, two school of Kathak came into existence. One was Lucknow and other was Jaipur school of Kathak. Also, Technique developed and established in different Gharanas was different owing to their origin, traditional background and the socio-political environment of their respective places.

Lucknow School of Kathak included graceful, Lyrical decorative, suggestive and sensuous movements. New Gats, Rasa Leela accompanied with the singing style of Thumris were introduced which employed very graceful movements in the Kathak framework. In the Nritta portion, small Tukdas were danced in which stress was laid on the beauty of the body parts.

Jaipur Gharana made its landmark in Nritta, an element of mechanical display. It attached prominence to tandava style i.e. virile type of movements and thus rhythmic acrobatics played a major part in this Gharana. Layakari, the intricate time measurements in footwork became the keynote of Jaipur Gharana. Also, attention was given to the execution of the bols of pakhawaj and tabla through footwork in this form.

Thus, Changes in the Technique of Kathak were observed within the boundaries of Kathak in the form of it's two Schools thus depicting the scope of bringing in further changes in this aspect of Kathak in the future Generations.

\section{TECHNIQUE USED BY THE NAUTCH GIRLS IN THE BRITISH PERIOD}

With the advent of the British rule, the classical dance form got shifted from its original purpose of devotion and found place in the Chambers of Tawaifs or prostitute dancers who came to be known as the Nautch girls. Technique of Kathak used by these Nautch Girls is discussed by some of the Britishers:

"Charles ${ }^{2}$ Doyley in his book, The European in India, published in 1813, gives the following account of a dancing woman of Lucknow. 'The dancing women of India have no variety of steps, the feet kept close and parallel, one foot advancing a few inches and other foot following it; is however done with remarkable exactness as to times which, on all occasions, is regulated by instruments played by men."[Projesh Banerjee, 1982]

"Prince Victor of Cooch ${ }^{3}$ Behar describes : 'For the most difficult feat which the Nautch girls have to perform is the walk. The perfect walk is the Neplvs ultra of the Nautch, and to watch a Nautchwali gliding effortlessly across the floor is the personification of the art.' (The illustrated weekly of India, Feb18, 1940). [Projesh Banerjee, 1982]

From above, it may be assumed that Kathak in the British period was very graceful. Technique included lesser variety of steps performed with high degree of exactness and perfection. Gliding effortlessly, their specific walk etc. were also included in the repertoire of Kathak which got elaborated as Thata and Gat Nikas in the modern times.

1 Projesh Baanerjee - Kathak Dance Through the Ages

2 Projeh Banerjee - Kathak Dance Through the Ages

3 Projesh Banerjee - Kathak Dance Through the Ages 
Thus, we can say that delicate aspects of Kathak further developed in the Technique of the art form during the British rule.

\section{CONTRIBUTION OF RAJA CHAKRADHAR SINGH OF RAIGARH}

A few Rajas of North India especially Raja Chakradhar Singh of Raigarh helped in preserving the traditional format of Kathak.

Changes were observed in the Technique of Kathak in Raigarh. Bols used in Raigarh Darbar were onomatopoetic and could draw the visual picture even while recited in Padhant. Infact, technical pieces of Kathak were composed and named according to these Bols. e.g. Trotting of horses resulted in the creation of Ashwa Paran while onset of monsoons with the accompanying thunder lightning, rainfall led to the creation of Jhoolna Paran.

Thus, various new technical pieces like the Ashwa Paran, Jhoolna Paran etc. came to be added in the repertoire of Kathak. As per Mandvi Singh ${ }^{1}$ (1990), Raja Chakradhar Singh laid down the foundation of bringing Gurus of different Gharanas to one centre i.e. Raigarh who were initially scattered in the different provinces of India. "Raigarh mein Raja Chakradhar Singh ne apne darbar mein Kathak ke sabhi samkaleen aacharyon ko aashrya diya tha aur kai varsho tak Kathak mein nitya naye prayog karte rahe. Phir apne swarachit 'Nartan Sarvasama' mein ankit kiya"

Thus, bringing the Gurus to one centre helped in the intermingling of the Technical aspects of the various Gharanas and sowed the seeds of Kathak in the Modern Times.

\section{IMPACT OF TECHNOLOGY AND FUSION OF CULTURE ON THE TECHNIQUE OF KATHAK IN THE MODERN WORLD}

Mutations are observed in the Technique of Kathak in the Modern Period. Demand of time has led to the Presentation of Kathak at a faster tempo which has also influenced the movements used in the Technique of Kathak.

Relating to this, Shovana Narayan says that, "Trend in the 60 's saw ${ }^{2}$ a lessening of the arm movements while executing patterns at a fast tempo. 80's and 90's saw a further reduction in the extension of arms while dancing at a fast tempo. Similarly, position of the elbows which assumed a higher position has been lowered over the years. Movement of the present generation of the dancers vary greatly from the dancers of earlier generations even within the same gharanas." [Shovana Narayan,2004]

Thus, changes have been observed in the body movements of the Kathak dance in the modern era which further reflects innovations in the Technique of the dance form. As quoted above, due to the increased speed of the performances, there has been reduction in the extension of the arm movements in Kathak. The position of the elbow has also lowered in the basic stance of the dance form since the last few years.

Simultaneously, various experiments have also been done in the field of Kathak by presenting it with other dance forms by the masters of the Art. Few of them have successfully tried to incorporate Elements of Martial arts, Chau, Non-Indian dance forms like Flamenco and Western classical Ballet into Kathak and thus have done changes in the body and foots movements of the dance form in their compositions. Examples of few of such artistes are as follows:

- Aditi Mangaldas, a well known artiste of the innovative style of classical dance, Kathak, has added movements of Kalaripayatu and Chau to the dance form in one of her production 'Timeless' and 'Now is'. In fact, in these productions, she has fused various front stretches and side stretches, different types of jumps and leaps, different styles of claps with the technical hand movements and complicated footwork of Kathak, thus adding to the innovations done in the

1 Mandvi Singh - Bhartiya Sanskriti mein Kathak Parampara

2 Shovana Narayan - Kathak- Rhythmic Echoes \& Reflection 
technical elements of the dance form. Also, in few of her other works like 'Now is' and 'Inter-rupted', she has employed various movements of the floor.1

- Quincy Charles, an upcoming Kathak artiste, has used movements of gymnastics as well as the movements of Chaau for one of his works done with another well known Kathak artiste, Isabell, which was premiered in Kamani auditorium in Delhi.2

- In one of the works, Kathak artistes, Sanjukta Sinha and Aakash Odedra, have added contemporary dance movements to Kathak dance form thus highlighting the innovative work done by them in the technical aspects of Kathak.3

- Kumudini Lakhia has added a new texture to the rhythm by dividing a technical piece of Kathak i.e. Tihai among 3 dancers in one of her Kathak Productions, "Dhabkar."4

Hence, all the above mentioned artistes portray the changes done by them on contemporary lines in the technique of the dance form. Apart from this, the 'Gharanedar 'Kathak exponents have also done innovations in the technique of the dance form, by bringing out changes in the traditional movements while maintaining the boundaries of Kathak. A few of such examples are as follows:

- Krishan Mohan Mishra, presently working as a Kathak guru in the National Institute of Kathak, Delhi, has also done innovations in the technique of the dance form. For example: One of the movements of Kathak, which however resembles the 'leaps ' of the Russian Ballet, but is used for depicting terminologies like 'Dhilang' in Kathak, is generally done by opening both the arms in the same direction, by the present day artistes. Krishan Mohan Mishra has done innovations in this technical movement of the dance form by opening both the arms in the opposite directions rather than in the same direction. 5

- In the interview of another ' Gharanedar ' artiste, Ram mohan Maharaj, he has mentioned that while remaining within the boundaries of Kathak, he has knitted 'That', a technical element of Kathak, with Bhava and named it 'Sringarik That'. In it, he depicted the plucking of a flower and adorning it in the hair, the combing of hair, opening of the jewelry box, taking out of necklace and wearing it by the nayika. Thus, all these activities of 'Shringar' are portrayed through the medium of 'That' and hence it is named as 'Shringarik That' which is considered as an innovation in the Technique of Kathak. 6

Summing all above, we can say that there has been drastic change in the technical format of Kathak in the modern era. The use of broader bodily movements and facial expressions by artistes like Aditi Mangaldas or the fusion of technical movements of Kathak with movements of other dance forms like with contemporary dance by Sanjukta Sinha and Akaash Odedra and with Kalaripayatu by Aditi Mangaldas as well as the changes done in the traditional movements of Kathak by 'Gharanedar' artistes like Ram Mohan Maharaj and Krishan Mohan Mishra, all these are included in the innovations done in the Technique of the dance form by both the streams of Kathak artistes under the impact of Globalization of the present world

\section{CONCLUSION}

Concluding the work, we can say that changes have taken place in the technical aspects of Kathak throughout the different historical epochs . These changes or Innovation in one time have now become a part of the Tradition today and are considered important for the nourishment of the dance form.

1 As per performed with the artiste in the said Production

2 As per observed the performance

3 (https://youtu.be/0WoLTB7XnaM )

4 As per the Interview taken of the said Artiste

5 As per the interview taken of the said Artiste, on 2 May, 2012

6 As per the Interview taken of the said Artiste, 18 November, 2015

Swar Sindhu : A National Peer-Reviewed Journal of Music | UGC approved 63647 
"The old traditions may be ${ }^{1}$ explored but they should be adapted to modern trends. To come out of the well built paths of tradition, and to walk on new paths is a painful process, but it is absolutely necessary for the growth and progress of both arts and artist." (Projesh Banerjee, 1983)

Thus, such Innovations in the technique of Kathak have not only brought a change in the format of the art but also have helped in the enrichment of the classical dance thus presenting it as a highly sophisticated and polished art form on the Global Platform.

\section{BIBLIOGRAPHY}

Banerjee Projesh (1982) Kathak Dance Through the Ages, Cosmo Publications, New Delhi. Devi Ragini (1972) Dance Dielects of India, Vikas Publications, Delhi.

Gupta Bhartit (2004) Kathak Sagar, Radha Publications, New Delhi.

Kothari Sunil (1989) Kathak, Abhinav Publications, New Delhi

Massey Reginald (2004) India's Dances- Their History, Technique and Repertoire, Abhinav Publications, New Delhi

Narayan Shovana (2005) Indian Classical Dance, Shubhi Publications, Gurgaon

Narayan Shovana (2004) Kathak- Rhythmic Echoes, Publisher Wisdom Tree, Delhi.

Saxena Kumar Sushil (2006) Swinging Syllables Aesthetics of Kathak Dance, Sangeet Natak Academy, New Delhi

Singh Mandvi (1990) Bhartiya Sanskriti mein Kathak Parampara, Swati Publications, Delhi

Vir Avtar Ram (1984) Indian Dances- History \& Technique, Pankaj Publications, New Delhi.

Vatsayayan Kapila (1965) The Dance in India, Taraporevala's Treasure House of Books, Bombay

1 ProjeshBanerji - Kathak Dance Through Ages 